IZA DP No. 9794

International Migration:

Driver of Political and Social Change?

Michele Tuccio

Jackline Wahba

Bachir Hamdouch

March 2016 


\title{
International Migration: Driver of Political and Social Change?
}

\author{
Michele Tuccio \\ University of Southampton \\ Jackline Wahba \\ University of Southampton \\ and IZA \\ Bachir Hamdouch \\ INSEA-University Mohammed V Agdal \\ Discussion Paper No. 9794 \\ March 2016 \\ IZA \\ P.O. Box 7240 \\ 53072 Bonn \\ Germany \\ Phone: +49-228-3894-0 \\ Fax: +49-228-3894-180 \\ E-mail: iza@iza.org
}

Any opinions expressed here are those of the author(s) and not those of IZA. Research published in this series may include views on policy, but the institute itself takes no institutional policy positions. The IZA research network is committed to the IZA Guiding Principles of Research Integrity.

The Institute for the Study of Labor (IZA) in Bonn is a local and virtual international research center and a place of communication between science, politics and business. IZA is an independent nonprofit organization supported by Deutsche Post Foundation. The center is associated with the University of Bonn and offers a stimulating research environment through its international network, workshops and conferences, data service, project support, research visits and doctoral program. IZA engages in (i) original and internationally competitive research in all fields of labor economics, (ii) development of policy concepts, and (iii) dissemination of research results and concepts to the interested public.

IZA Discussion Papers often represent preliminary work and are circulated to encourage discussion. Citation of such a paper should account for its provisional character. A revised version may be available directly from the author. 


\section{ABSTRACT}

\section{International Migration: Driver of Political and Social Change?}

This paper focuses on the impact of international migration on the transfer of political and social norms. Exploiting recent and unique data on Morocco, it explores whether households with return and current migrants bear different political preferences and behaviours than nonmigrant families. Once controlling for the double selection into emigration and return migration, findings suggest that having a returnee in the household increases the demand for political and social change, driven by returnees mostly from Western European countries, who have been exposed to more democratic norms at destination. However, we find a negative impact of having a current migrant on the willingness to change of the left-behind household, driven by migrants to non-West countries, where the quality of political and social institutions are lower. Our results are robust to also controlling for destination selectivity. Finally, findings suggest that migration not only affect political attitudes but also actual behaviour: regions with higher returnee shares have had greater participation rates in the 2011 political elections.

\section{NON-TECHNICAL SUMMARY}

Does international migration act as a driver of political and social change? We look at the interesting case of Morocco, a North-African country that has become a major emigration hub to Europe and where there have been insistent calls for political change over the last few years. We exploit a recent and unique dataset in order to test whether returnees have different political behaviours and preferences than non-migrants. Overall, our findings suggest that international migration can be a driver of political and social change. However, the impact of host countries matters, as newly acquired norms and attitudes are not always "superior" to the norms at origin. This implies an eventual benefit for migration to Western countries, where the level of democracy and institutional quality is greater than in the rest of the world, and hence there is potential for positive transfer of norms from host to home countries.

JEL Classification: $\quad$ D72, F22, O15, O55

Keywords: international migration, political change, transfer of norms, Morocco

Corresponding author:

Michele Tuccio

Economics Department

School of Social Sciences

University of Southampton

Southampton, SO17 1BJ

United Kingdom

E-mail:m.tuccio@soton.ac.uk

\footnotetext{
* We would like to thank Michael Clemens and Mathis Wagner for helpful discussion. We are also grateful to seminar participants at the World Bank, Centre for Global Development, Paris School of Economics, and University of Kent for useful comments. Funding from the Economic and Social Research Council (RES-167-25-0678) is gratefully acknowledged. Any remaining errors are ours.
} 


\section{Introduction}

In early 2010s the Arab world saw a revolutionary wave of protests spreading throughout the region, sparked by dissatisfaction with the rule of governments, as well as human rights violations and political corruption. By 2014, civil uprisings had been spread across the Arab countries, most notably in Tunisia, Egypt, Libya, Yemen, and Syria. Everybody was asking for one thing: change.

A salient feature of all those troubled Arab countries - with the exception of Libya is that they have high emigration rates. Hence, an interesting question given this context is whether international migration is a driver of political and social change. More precisely, are returnees more likely to ask for change than non-migrants? Do migrants catalyze the diffusion of new values? This paper explores the migration-induced transfer of political and social norms and its linkages with political outcomes. It examines whether international migrants contribute to a change in preferences and behaviors by channelling modern political norms from destination to origin countries. In addition, it investigates the importance of destinations in the adoption of less traditional values, since newlyincorporated norms vary according to the level of democracy and political accountability in host countries.

We focus on a North African country - Morocco - which is one of the world's leading emigration countries, with an estimated 4.5 million Moroccans residing abroad in 2014, approximately 13 percent of the population. In particular, more than 3 million Moroccans are living in Europe making them one of the largest migrant communities in Europe (Hamdouch \& Wahba (2015)). At the same time, Morocco has seen instigating calls for political change over the last few years. Inspired by the wave of protests in the neighboring countries, demonstrations have been rallied during 2011-2012 to fight government corruption, the lack of civil rights and the absence of legitimate elections.

The main aim of our analysis is to test the potential causal link of these two key features of Morocco: that is, whether political attitudes are shaped by migration. Empirical studies on the impact of international migration on political norms are very recent, e.g. Spilimbergo (2009), Batista \& Vicente (2011) and Omar Mahmoud et al. (2014). However, most of those studies do not observe directly how migration affects the political views of 
the migrants or their households. The contribution of our paper to the current literature is straightforward. We are the first study directly looking at the effect of international migration on political attitudes and preferences, and being able to identify the underlying mechanisms behind the potential impact of migration. In fact, whilst all previous works used cross-country data of aggregate migration flows or the share of migrants in a given community, we are able to exploit information at the individual and household level. Moreover, former literature adopted proxies of political beliefs, such as institutional quality and democracy, which do not capture entirely individuals' preferences nor measure the likelihood of migrants to act as a catalyst of political change. On the contrary, we exploit unique information on migration experiences and political and social norms at individual level, allowing a direct estimation of the impact of migration on the preference for change.

We also contribute to the literature by comparing the different impacts of returnees and diaspora on political and social change. While most previous studies have focused on a single category of migrants (exceptions are Batista \& Vicente (2011) and Omar Mahmoud et al. (2014)), only an overall analysis of all types of international migration can give a clear picture of the mechanisms behind the migration-induced transfer of norms. We hence compare the attitudes of returnees to the ones of non-migrants, as well as the norms of the left-behind household members of current migrants to those of non-migrants. In doing so, we address the double selection into emigration and into return migration, since both migrants and returnees are not a random sample of the population, but they may be selfselected on the basis of observed and unobserved characteristics. We tackle endogeneity and selectivity issues by adopting a multi-equation mixed system, where both emigration selectivity and selection into return migration are taken into account. Importantly, we also show robustness of our results to addressing an additional source of selectivity, that is self-sorting into destination countries. Indeed, this may be a remarkable source of bias in previous literature on the migration-induced transfer of norms. Up to our knowledge, we are the first study simultaneously tackling selection into emigration, selection into return migration, and selection into destination.

In addition, we also make use of the heterogeneity of Moroccan emigrants' destinations in order to corroborate the findings on the importance of host countries. Variability in destinations of Moroccans to Western and Arab countries allows us to estimate opposite 
preferences for political and social change according to the institutions in place abroad. Finally, we examine whether the impact of migration on norms affect outcomes and not only attitudes. Hence, we show how a greater exposure to return migration is correlated with higher turnout rates to the 2011 parliamentary elections.

Very few studies have examined the impact of migration on the transfer of norms so far. Focusing on the quality of institutions, and using panel data for bilateral student flows from 1950 to 2003, the seminal work of Spilimbergo (2009) provides evidence that foreigneducated individuals promote domestic democracy, but only if the level of democracy in destination countries is high. Also at macro level, Beine \& Sekkat (2013) broaden the analysis by looking at the impact of emigration on the quality of institutions, pointing at a positive and significant effect of international migration on the change in institutions. Findings are confirmed by Docquier et al. (2016), who restrict the focus to developing countries. Batista \& Vicente (2011) customize a survey of perceived corruption in public services in Cape Verde, where they additionally ask respondents to mail a pre-stamped postcard if they wanted the anonymous results of the survey to be made publicly available in the media. Interestingly, localities with high international emigration prevalence had higher demand for political accountability.

Electoral data are exploited so far by three studies. Firstly, looking at the 2000-2002 Mexican municipal elections, Pfutze (2012) estimates that one percentage point increase in the proportion of migrant households in a municipality increases the probability that a party in opposition to the former state party would win the elections by more than half a percent. Secondly, Chauvet \& Mercier (2014) use electoral data from Mali in order to explore the link between return migration and political outcomes. They find that localities with greater shares of returnees from non-African countries are more likely to bear higher electoral participation rates. Thirdly, Omar Mahmoud et al. (2014) provide evidence that Moldovan municipalities sending migrants to democratic countries experience an increase in political support for more democratic and liberal parties in elections.

Our estimates suggest that, once controlling for selections, return migration boosts the demand for political and social change in Morocco. Results are driven by returnees from the West, which have been exposed to more democratic norms at destination. On the contrary, households with a current migrant are on average less likely to ask for change 
than non-migrants families, driven by migrants to non-Western countries. Findings are robust to different specifications, sub-samples and techniques. As a robustness check, we also present results based on the 2011 World Value Survey and the 2004 Census, showing that returnees affect attitudes besides their own households in the region where they live. In addition, we show that return migration is associated with outcomes such as the turnout for elections, as we find that regions with larger returnee shares are more likely to have greater turnout to the 2011 political elections.

The remainder of the paper is structured as follows: Section 2 introduces stylized facts from migration patterns in Morocco, as well as data and summary statistics from our analysis. Section 3 presents our methodology and econometric approach. Estimation results on return and current migration are discussed in section 4, whilst Section 5 presents extensions to the analysis. Section 6 concludes.

\section{The case of Morocco}

\subsection{Migration in Morocco}

Over the last decades, Morocco has become one of the world's leading emigration countries. Over 4 million Moroccans are estimated to be living abroad. Almost three million Moroccans live in Europe. The largest concentration of Moroccans living abroad is in France. In the Netherlands, Moroccans are the third largest group and in Belgium Moroccans are the largest group of non-EU immigrants. Yet, in terms of absolute numbers of Moroccans, Spain hosts the second largest Moroccan diaspora followed by Italy. At the same time, the remainder of Moroccans is dispersed in the US and Canada among other countries, whilst about 5 percent are in other Arab countries. ${ }^{1}$

Seasonal and circular migration patterns within national borders have characterized Morocco's pre-colonial population history for centuries. However, the great migration boom has exploded only in the 1960s, when the European economies were rapidly expanding in the aftermath of the II World War and were in need of unskilled labour for their mining, industry and construction sectors. Until the mid of the 1970s economic and oil crisis, both Moroccan emigrants and host countries were expecting migration to be

\footnotetext{
${ }^{1}$ See Khachani (2012) and de Haas (2014) for a survey on migration trends in Morocco.
} 
temporary in nature, and return migration was a key feature of the Moroccan diaspora. On average, Moroccans resided from seven to ten years in Europe and then returned home (Hamdouch \& Wahba (2015)), but the following period of economic stagnation led European governments to close their borders to new migrants, and many Moroccans decided not to return but stay in their host countries. It was mainly through family reunification programme and irregular migration that the Moroccan diaspora in Europe managed to grow steadily.

A direct consequence of the restriction of immigration policies in northwest Europe was a diversification in migration patterns. Many new Moroccan immigrants shifted from classic destinations, such as France, Belgium, Germany and Netherlands, to the southern countries of Spain and Italy, where undocumented trespassing or overstaying was easier. Similarly, a significant number of Moroccans migrated to Libya and oil-producing Gulf countries, as well as to United States and French-speaking Canada.

Despite return migration is relatively less important in Morocco than in other Middle Eastern and North African neighboring countries, it is certainly a growing feature, especially over the last few years, when the financial crisis lowered economic opportunities everywhere, and in particular in those countries where Moroccan immigration is important, such as Spain and Italy. However, national estimates of Moroccan returnees are out-dated. The only national data available are those of the 2004 population census, which indicates an average of 33,100 returnees per year. ${ }^{2}$ As mentioned by de Haas (2014), migration data from European destinations suggest that about a quarter of Moroccans who migrated between 1981 and 2009 returned to Morocco. Also, the share of returnees fluctuates with the business cycle in Europe.

As a result of the lack of data, researches on return migration in Morocco are rather limited. A few studies though have examined the impact of return migration on the economic development of Morocco and in particular on the returnees' occupational choice and entrepreneurship. Using detailed survey data collected by the Centre for Studies and Demographic Research (CERED) at the High Commission of Planning (HCP) in 2003-04 on return migrants in two main regions of Morocco (Great Casablanca and Souss-Massa-

\footnotetext{
${ }^{2}$ This estimate is eventually an underestimation of the real extent of return migration, since it does not take into account undocumented and illegal migration.
} 
Draa), Hamdouch \& Wahba (2015) examined the determinants of entrepreneurial behavior among return migrants, controlling for the potential endogeneity of migration duration, and the potential endogenous impact of having invested overseas. Another exception is Gubert \& Nordman (2011) who using the DReMM data explored the occupational status of returnees in Morocco and in the whole of the Maghreb.

To our knowledge, this is the first paper examining the impact of both current and return migration on political and social attitudes in Morocco. Although Morocco has not seen the turmoil caused by the Arab Spring in other parts of the Arab world, intense prodemocracy demonstrations have been put in place in 2011 by the "February 20 Movement" against the political, social and economic conditions. As a result, a new constitution was adopted by referendum in July 2011 aimed at improving democracy and the rule of law.

\subsection{Data and Descriptive Statistics}

The analysis of this paper is based on a new and unique dataset, the "Investigation on the Impact of International Migration on Development of Morocco" (IIIMD), produced by the Association Migration Internationale with the support of the International Organisation for Migration and the Ministry for the Moroccans Residing Abroad and Emigration. The investigation has been conducted in August-October 2013 for about 1,200 households. Since the investigation is national in scope, it covers the entire national territory. It is conducted with a representative sample of all private households in Morocco (including those composed of foreign individuals), representing the 16 regions of the country in the two areas of residence (urban and rural). The observed units consist of both households having no migrant member, households with one or more migrants currently abroad, households with one or more returnees, and households with at least one immigrant. ${ }^{3}$

The sampling has been conducted randomly on the basis of a previous survey (the 2009-2010 National Demographic Survey (ENDPR)), which itself has been constructed through randomization. ${ }^{4}$ In a first step, 62 primary units are randomly selected from the

\footnotetext{
${ }^{3}$ See Hamdouch \& Mghari (2014) for a detailed description of the data and its sampling methodology.

${ }^{4}$ Specifically, the sampling of the 2013 IIIMD was based on the "National Population Survey with Repeated Passages" (ENDPR) undertaken by the Haut Commissariat au Plan in 2009-2010 on 105,000 households, which is itself derived from the randomized sample of the "General Census of the Population and Housing" (RGPH) developed in 2009-10 by the Moroccan Department of Statistics in order to meet the needs of household surveys programmed during the intercensal period 2005-2014.
} 
ENDPR survey proportionally to the size of the units in terms of density of the various types of migrants (returnee and current). Then two secondary units are randomly drawn in each primary unit (with equal probabilities). Lastly, 10 households are selected with equal probabilities in each secondary units.

The dataset contains unique features that are key for our analysis. Firstly, it includes questions on non-migrant, current and return migrant households, which can be exploited to compare different types of migration experiences, and also to control for the double selection into emigration and return migration. Specifically, the observed units consist of both households having no migrant (243), households with one or more migrants currently abroad (658), households with one or more returnees (228), and households with at least one immigrant (105).

Table 1 compares destination and education levels of current and return migrants. Host countries are similar for both types of migrants. Interestingly, France, Italy and Spain have been preferred as main destinations by over 75 per cent of migrants. On average, return and currents migrants have spent the same time abroad (11 years), which is consistent with the aforementioned stylized fact that nowadays Moroccans tend to stay longer at destination, due to restrictive immigration policies which would impede them to return to the host country if they leave. On the other hand, education attainment differs greatly among migration experiences. Returnees are less educated, with 41 per cent of no-schooled individuals, whilst only 11 per cent of current migrants have not undertaken formal education. Conversely, over 40 per cent of current migrants hold a secondary or higher degree, a proportion which is halved for returnees.

A second distinctive feature of the IIIMD is the inclusion of questions on the willingness to change the social and political landscapes, which are a direct measure of individuals' attitudes and beliefs. For instance, we exploit a set of variables included in the IIIMD on political and social norms, administered to both households with a returnee, families with a current migrant abroad, and non-migrant households. Our analysis will be based on 5 questions on the willingness to innovate the traditional Moroccan society and politics: (1) "Are you happy about how Morocco is administered?" (2) "I think we should defend the traditional lifestyle in Morocco." (3) "We need to make more effort in order to treat men and women equally." (4) "We need to make more effort in order to treat everybody 
equally." (5) "I think people should be more involved in the decision-making process."

We adopt several dimensionality reduction techniques in order to aggregate the 5 aforementioned variables into a composite index of political and social norms. Nevertheless, we also run specifications with each single indicator as dependent variable to show that our results are not driven by the construction of the composite index. In our benchmark analysis, we use Principal Components Analysis (PCA), which has been extensively used to construct multidimensional and composite indices (Filmer \& Pritchett (2001)). Its clear advantage is to measure the group of weights which explains the largest variation in the original variables. The robustness of our composite indicator is tested by using two additional weighting techniques. Firstly, we adopt Multiple Correspondence Analysis (MCA), which has been often preferred to analyze qualitative, categorical and binary variables (Asselin (2002)). Secondly, we make use of equal weights, that have been largely used for their simplicity and apparent objectivity (Tuccio \& Wahba (2015)).

The proposed index of political and social change is constructed such that it takes values from 0 , corresponding to preference for no change, to 1 , meaning complete preference for change, and it is given by:

$$
Y_{i}^{j}=A_{i 1} W_{1}^{j}+A_{i 2} W_{2}^{j}+\ldots+A_{i q} W_{q}^{j}
$$

where $Y_{i}^{j}$ is the value of composite index $Y$ for individual $i$ using the weighting technique $j$ (namely, PCA, MCA and equal weights), $A_{i q}$ is the answer of individual $i$ to question $q$ and $W_{q}^{j}$ is the weight obtained using the $j$ methodology applied to question $q .{ }^{5}$

The analysis of this paper is restricted to individuals in the working age $(15-65$ years old) at the time of the survey, in order to exclude those individuals whose political norms may be very different due to their young or old age. Moreover, we exclude from the analysis migrants who left the country for political issues, as well as returnees who came back to Morocco for political reasons, since they would bias our estimates. Finally, immigrants are not taken into account as non-migrant households, carrying a different set of political and social norms than natives.

\footnotetext{
${ }^{5}$ Table A1 in Appendix lists the 5 variables that are used to construct the Political and Social Change Index and the respective weights using PCA, MCA and equal weights. Remarkably, larger weights imply greater preference for political and social change.
} 
Table 2 compares characteristics of individuals with a returnee among their family members, individuals with a current migrant, and individuals from non-migrant households. It appears clear that, without controlling for selectivity issues, individuals in our sample do not differ along most of characteristics. In particular, our outcomes of interest (i.e. the five proxies of political and social change, as well as the three different composite indicators using PCA, MCA and equal weights) do not suggest specific differences among migration experiences. Econometric techniques are therefore required in order to better understand the impact of international migration on political norms.

\section{$3 \quad$ Methodology}

\subsection{Empirical Strategy}

We first focus on returnees. We are interested in understanding whether returnee households differ in their political norms from non-migrant households. We therefore model two interrelated decision: the propensity to want change (equation 2) and the probability of being a returnee (equation 3). The preference for change in the political and social landscapes is proxied by the constructed composite indicator $Y_{i}$.

$$
Y_{i}=\alpha_{0}+\alpha_{1} R_{i}+\alpha_{2} X_{i}+\alpha_{3} F_{r}+\epsilon_{i}
$$

In equation $2, Y_{i}$ is the level of political and social change desired by individual $i$, which can take any value between 0 and 1 , where 0 means no change and 1 implies complete change. $R_{i}$ is the return migration variable, a dummy being 1 if the individual has at least a returnee member within the household. $X_{i}$ is a vector of individual's characteristics, including age, educational attainment, marital status, employment status, living in a rural area or in a metropolis (3 biggest Moroccan cities: Casablanca, Fes, Rabat-Sale), being the head of the household and a dummy for owing the accommodation, a proxy for wealth. Fixed effects at regional level are absorbed by $F_{r}$, while $\epsilon_{i}$ is a zero-mean error term.

The return migration decision is instead denoted by $R$ and is observed only when the 
latent variable measuring the gains from being a return migrant $\left(R^{*}\right)$ is positive.

$$
\begin{cases}R=1 & \text { if } R^{*}>0, M>0 \\ R=0 & \text { otherwise }\end{cases}
$$

However, we need to introduce a third decision, since return migration is only measured if the individual has emigrated. Hence $R$ is only observed if an individual has emigrated, i.e., $M>0$. The emigration decision $(M)$ is observed when the latent variable measuring the gains from migration $\left(M^{*}\right)$ is positive.

$$
\begin{cases}M=1 & \text { if } M^{*}>0 \\ M=0 & \text { otherwise }\end{cases}
$$

We therefore estimate a multi-equation mixed system, where the three decisions above are estimated simultaneously using a Conditional Mixed Process (CMP) estimator (Wahba (2015)). CMP fits a Seemingly Unrelated Regressions (SUR) framework, in which regressors seem unrelated as no endogenous component appears as explanatory variable in the other equations, although their errors can be correlated (Roodman (2011)). In CMP, equations may vary in sample sizes: selection equations will be modelled for the full data set, while the dependent variable of interest in equation (2) for the subset with complete observations.

Although our data allow us to control for observables variables affecting the selection of migrants, unobservables may still induce those who have migrated to be self-selected on the basis of some latent characteristics. If both emigrants and return migrants are not a random sample of the Moroccan population, estimates would be biased.

\subsection{Identification}

The correct identification of the full structural model requires two valid exclusion restrictions for the emigration and return decisions. For the emigration decision, we construct a proxy for the attractiveness of the foreign labour market in each year. Specifically, 
our measure is given by:

$$
A_{t}=\max \left(G_{j t}-G_{m t}\right) W_{j}^{1990}
$$

$A_{t}$ is the most attractive foreign labour market at time $t . G_{j t}$ is the GDP per capita growth rate of destination $j$ at time $t$, whilst $G_{m t}$ is the growth rate of Morocco at time $t$. This measure of foreign attractiveness is weighted by the size of the diaspora given the importance not only of economic factors, but also of social networks in emigration. Weights $W_{j}^{1990}$ are constructed as follows: using data from Özden et al. (2011), we take the share of Moroccan stocks, in each destination country $j$, in the total Moroccan migrant population in 1990 . We adopt $A_{t}$ for when the individual was 23 years old, which is the average year of finishing education, assuming that this is the time in which individuals enter in the labour market. However we also check the robustness of our results using alternative age, between 25-30 years of age. ${ }^{6}$ Clearly, the attractiveness of foreign countries relative to Morocco in the past when the individual was 23 should have no bearing on their opinion at the time of survey in 2013 when the average age of non-migrant is 49 and 54 years of age in the case of return migrants.

For the return migration decision, we construct a dummy including several exogenous shocks that induced Moroccan emigrants to come back to their homes. Firstly, the explosion of the Gulf War in 1990 has led to a great out-migration of Moroccan migrants from oil-producing Gulf states. Secondly, in 2000 xenophobic uprising exploded in Libya, triggered by the rising unemployment of natives, inconstancy in migration policy and an increasing presence of foreign workers (Migration Policy Centre (2013)). Unrest led to the deaths of hundreds of foreigners, encouraging many immigrants working in Libya to return to their origin countries. Thirdly, in 2004 film-director Van Gogh was murdered by Moroccan Mohammed Bouyeri in Amsterdam. The murder sparked a violent storm of outrage and grief throughout the Netherlands, which may have lead some Moroccan immigrants to return home.

In our shock variable we also include two new legislations emanated in destination countries where Moroccans were more present, as they have been particularly restrictive against undocumented migrants, and consequently they have provoked an inflow of Mo-

\footnotetext{
${ }^{6}$ See Table A2 in Appendix.
} 
roccans back home. In total, 16 percent of our sample of returnees came back to Morocco due to these two shocks. For instance, in 2006 France approved a new immigration law that toughened up restrictions on immigrants who do not have skills and qualifications targeted by the French government as important to France (Chou \& Baygert (2007)). Previously, illegal immigrants in France could obtain documents to ensure legal status if they could demonstrate a stay in-country of ten years or more, whilst with the new law these regulations were scrapped. Moreover, the government planned approximately 26,000 deportations in that year only, due to the high volume of undocumented immigrants. Similarly, a new immigration law was passed in Italy in 2009 according to which illegal immigration became an official crime, and as such helping or housing undocumented migrants resulted prosecutable in court. Employment of irregular migrants became punishable with up to 5 years of imprisonment. Teachers in schools were also compelled to report undocumented children to officials.

It is worth stressing that, while these shocks increased the propensity to return home in a given year, they did not affect the probability of emigration given the multiple available destinations. Figure A1 in Appendix shows graphically that our chosen shocks are not associated with a decrease in the magnitude of emigration from Morocco. In addition, negative past shocks in destination countries are clearly not directly correlated with Moroccans' political and social norms in 2013, as opinions are measured back home on issues such as gender equality, for example whether individuals think we should make more effort to treat men and women equally, or on local matters such as traditional lifestyle in Morocco.

We therefore obtain a system of three equations as follow:

$$
\left\{\begin{array}{l}
Y_{i}=\alpha_{0}+\alpha_{1} R_{i}+\alpha_{2} X_{i}+\alpha_{3} F_{r}+\epsilon_{i} \\
R_{k}=\beta_{0}+\beta_{1} S_{k}+\beta_{2} C_{k}+\beta_{3} F_{r}+n_{k} \\
M_{k}=\gamma_{0}+\gamma_{1} A_{t}+\gamma_{2} Z_{k}+\gamma_{3} F_{r}+\mu_{k}
\end{array}\right.
$$

In the return migration equation, $R_{k}$ is the linear probability of individual $k$ being a return migrant, conditional on being an emigrant, and $S_{k}$ represents the shock variable, constructed as previously explained. ${ }^{7}$ Controls $C_{k}$ are the characteristics of the returnee.

\footnotetext{
${ }^{7}$ Note that individuals $i$ in the first equation and $k$ in the selection equations may coincide or not.
} 
In the emigration equation, $M_{k}$ is the linear probability being an emigrant, whilst $A_{t}$ is the attractiveness of the foreign labour market. Controls $Z_{k}$ include the characteristics, such as age, sex, education, of the migrant and the household left behind.

\section{Estimation Results}

\subsection{Households of Return Migrants and Change}

We first look at the impact of having a returnee in the household on the preference for political and social change. The main outcome variable in Table 3 is the composite indicator of preference for change as previously constructed through Principal Component Analysis (PCA). Interestingly, no effect is found using a simple OLS estimator (column 1). However, controlling for selection into return migration and emigration leads to a strongly significant impact of return migration on the demand for political and social change (columns 2 and 3). This emphasizes that migrants are not randomly chosen among the Moroccan population, but are selected on the basis of some observed and unobserved characteristics. The sign of the relationship is positive: returnee households are more likely than non-migrants to ask for change. This may be due to the assimilation of more democratic norms while living abroad, a possibility which will be confirmed below by further analysis.

It is worth noting that both exclusion restrictions used to identify our full model works as expected. The shock dummy is a good predictor of the probability of being a returnee, while our measure of attractiveness of the foreign labour market also has a positive and significant impact on the likelihood of emigrating in a given year. Looking at the correlations among equations, results suggest a negative selection of both current and return migrants. However, those who returned to Morocco are positively selected among the migrants' pool. Return migration behaviors, therefore, accentuate the selection that characterized the initial emigration flows, as discussed by Borjas \& Bratsberg (1996).

To test the robustness of our findings, Table 4 shows results using two alternative

In particular, $i=k$ if the survey respondent $i$ is directly the family member who migrated. Conversely, $i \neq k$ if respondent $i$ is not the returnee $k$ himself. Importantly, we have only one - or maximum two individuals per household in the survey. 
outcome variables: the composite index of political and social change aggregated through Multiple Correspondence Analysis (columns 1, 2, and 3), and using equal weights (columns 4,5 , and 6 ). We can safely reject the eventuality that previous estimates were driven by the weighting technique used to construct the composite indicator, since return migration still bears a positive and significant effect on preference for change.

Results are also robust to the use of a different exclusion restriction for the selection into emigration equation (Table 5). We have constructed the alternative measure as follows: for each year, we picked the maximum attractiveness of the foreign labour markets in only the main destinations in each region, that is France for Europe, Canada for North America, and Libya for MENA. ${ }^{8}$ The instrument appears to be a strong predictor of the probability of emigration, leaving positive and significant the effect of return migration on attitude towards change.

Since results may be driven by the use of a composite indicators (regardless of the weighting technique applied), Table 6 shows specifications where the outcome of interest has been replaced by the single sub-indices. In particular, columns 1, 2 and 3 presents results using the dummy variable "I am not happy with how Morocco is run/administered" (proxy for political norms), whilst column 4, 5 and 6 use the dummy "We need to make more effort in order to treat men and women equally" (proxy for social norms). Findings are robust to this additional test too.

In order to understand the reasons behind the positive sign of the coefficient of return migration, and also to clarify whether migrants do actually transfer norms from host to home countries, we further disaggregates results by destination. By distinguishing between migrants from Western (Europe, US \& Canada) and non-Western (Arab) countries, we expect that returnees from more democratic countries should drive our results, as they have assimilated more equal and democratic values while living abroad. Columns 1 and 2 of Table 7 confirm our hypothesis: findings are driven by returnees from West countries, while the coefficient for non-Western returnees is not statistically significant. Comparing returnees from the West to returnees from non-Western countries suggests that the formers are more likely to demand change than non-Western migrants (column 3). This result is in line with the findings of de Haas \& Fokkema (2010), which, using

\footnotetext{
${ }^{8}$ On the contrary, the former instrument considered the whole world.
} 
semi-structured interviews in the Todgha valley, note that "exposure to European media and public discourse is likely to have influenced migrants' attitudes toward Moroccan lifestyle and bureaucracy. Also, migrants might attempt to present themselves as more modern and superior by dissociating themselves from Moroccan authorities and society."

A concern might rise on the exogeneity of the migration destination. In fact, it can be argued that more open-minded individuals may prefer to migrate in first place to the democratic Western countries. If this is the case, then the effect previously found would not be due to a migration-induced transfer of norms, but rather to a selection issue. In table A3 in Appendix we show evidence suggesting that our sample is not remarkably affected by this issue. Indeed, we exploit 3 variables included in the IIIMD database in order to proxy for open-mindedness ("Your main raison to emigrate was to improve your lifestyle"; "Overall, would you say you are happy to have lived abroad?"; "Would you like to migrate again abroad?"). We then run additional migration equation where the dependent variable is a dummy being 1 if the returnee lived in the West, whilst it is 0 if he/she lived in a non-West country. Importantly, we control for the 3 aforementioned proxies of open-mindedness (both separately in columns 1 to 3 , simultaneously in column 4, and aggregated in a composite indicator through PCA in column 5) and show that being more open-minded is not a major driver of migration towards more democratic Western countries. We then use the composite index of open-mindedness as additional control in column 4 of Table 7: results are robust, suggesting that selection into destination is not an issue in our sample. We will come back to the issue of the self-sorting into destination below, where we will test the robustness of our main findings to the addition of a further selection equation.

\subsection{Households of Current Migrants and Change}

We now turn to the impact of having a current migrant $E_{k}$ in the household on the preference for political and social change (Table 8). We estimate the following model:

$$
\left\{\begin{array}{l}
Y_{i}=\alpha_{0}+\alpha_{1} E_{k}+\alpha_{2} X_{i}+\alpha_{3} F_{r}+\epsilon_{i} \\
E_{k}=\gamma_{0}+\gamma_{1} A_{t}+\gamma_{2} Z_{k}+\gamma_{3} F_{r}+\mu_{k}
\end{array}\right.
$$


As before, in the political change equation $Y_{i}$ is the level of political and social change desired by individual $i$, which can take any value between 0 (no change) and 1 (complete change). In the emigration equation, $E_{k}$ is the probability of being an emigrant.

Caution is however required in estimating this model. In fact, emigration from Morocco is largely male-dominated, and consequently survey respondents in households with a current emigrant abroad are more likely to be left-behind women compared to non-migrant families where the male head is usually the respondent. As a matter of fact our data show that, whilst no woman has been interviewed among non-migrant families, one out of three respondents with a current migrant is a female. A clear bias may arise if men and women carry different social norms. Therefore in order to have comparable treatment and control groups, columns 1 to 4 of Table 8 exclude females from the estimation sample, although we show results with women included in columns 5 and 6 as robustness.

Remarkably, left behind households of current migrants have lower demand for political and social change across all specifications. Column 2 presents our benchmark results, controlling for selection into emigration and using the composite index constructed through PCA. Results are however robust to the use of MCA (column 3) and equal weights (column 4). It may be the case that current migrants are mostly the former heads of the household, which migrated abroad in order to provide for the left-behind family. If this was correct, comparing non-migrant households to respondents with a current migrant may again bias our estimates, since we might be comparing non-migrant heads of the family with sons or elderly of migrant heads, who may bear different social norms. This is the reason why column 5 includes only heads of the household from the analysis. In column 6 , we also test the robustness of our findings to focusing only on employed people, as we may want to restrict the analysis to individuals comparable in terms of their labour market status. Finally, column 7 is most parsimonious specification, where we focus only on male and employed heads of the household.

Regardless of the specification, results suggest a negative impact of current migration on political and social change, and according to our theoretical predictions this should be due to a stream of less democratic norms from destination countries. We therefore test this hypothesis by disaggregating between West and non-West migrants. Findings in Table 9 do confirm a transfer of norms and show that the negative coefficient of current migration is 
driven by migrants from non-West countries, which indeed have lower institutional quality and democracy levels than Morocco. When comparing migrants currently in the West to migrants in non-West countries, we notice that, conditional on migration, individuals in Europe and North America are more likely to transfer political change than migrants in the Arab world (column 3).

\subsection{Destination Selectivity}

Importantly, a still unexplored potential source of bias may derive from a self-selection process of migrants into destination countries. In fact, when deciding to emigrate, individuals may choose to move to specific locations according to unobservable (to the econometrician) characteristics or preferences. For instance, in the previous section and table A3 we provided evidence that open-mindedness does not affect our results on return migration. In table 10, we test the robustness of our main findings to the inclusion of an additional selection equation for self-sorting into West/non-West destinations. Specifically, our dependent variable is a dummy whether the migrant lived in the West or Arab world.

In order to estimate the model, however, a further exclusion restriction is needed, and remarkably this does not have to be correlated with the probability of emigration in the first place, nor the likelihood of return migration or social/political preferences in 2013. We hence construct the instrument as the ratio between GDP per capita growth in France versus Libya (the two main destination countries in the regions) as follows $F L_{t}=G_{\text {France }, t} / G_{\text {Libya }, t}$. Again we use the average age of finishing education and entering the labour market (i.e. 23 years of age). This would clearly affect the location where the migrant chooses to move, but not the migration decision itself. It is worth noting that our previous exclusion restriction for the selection into emigration expressed in equation 5 would be violated if we include the selection into destination equation in the simultaneous model. In fact, the most attractive foreign labour market would also affect the destination choice. Hence, we replace this instrument with the average attractiveness of the foreign market in time, as follows: $A V_{t}=\operatorname{mean}\left(G_{j t}-G_{m t}\right) W_{j}^{1990}$. We argue that $A V_{t}$ would capture more the push factor in determining migration: if Morocco is doing badly relative to on average all other countries, the individual decides to emigrate, otherwise they would 
not emigrate. Also, $F L_{t}$ (the ratio between GDP per capita growth in France versus Libya) when the individual first enters the labor market (at the age of 23 years) should not have any impact on the return decision nor on political and social preferences in 2013.

We estimate the following system to control for destination selectivity in the case of return migration.

$$
\left\{\begin{array}{l}
Y_{i}=\alpha_{0}+\alpha_{1} R_{i}+\alpha_{2} X_{i}+\alpha_{3} F_{r}+\epsilon_{i} \\
R_{k}=\beta_{0}+\beta_{1} S_{k}+\beta_{2} C_{k}+\beta_{3} F_{r}+n_{k} \\
D_{k}=\theta_{0}+\theta_{1} F L_{t}+\theta_{2} I_{k}+\theta_{3} F_{r}+\epsilon_{k} \\
M_{k}=\gamma_{0}+\gamma_{1} A V_{t}+\gamma_{2} Z_{k}+\gamma_{3} F_{r}+\mu_{k}
\end{array}\right.
$$

Similarly in the case of current migrants, we add the destination selection equation as follows:

$$
\left\{\begin{array}{l}
Y_{i}=\alpha_{0}+\alpha_{1} E_{k}+\alpha_{2} X_{i}+\alpha_{3} F_{r}+\epsilon_{i} \\
D_{k}=\theta_{0}+\theta_{1} F L_{t}+\theta_{2} I_{k}+\theta_{3} F_{r}+\epsilon_{k} \\
E_{k}=\gamma_{0}+\gamma_{1} A_{t}+\gamma_{2} Z_{k}+\gamma_{3} F_{r}+\mu_{k}
\end{array}\right.
$$

Estimates for both return migration (column 1) and the diaspora (column 2) show that self-selectivity into destination does not alter our results. We find that return migration increases the demand for political and social change, but households of current migrants are less likely to quest for change; i.e. our findings remain robust to this further test. Indeed, we find that there is positive selection between choosing Western countries relative to Arab countries and emigration. However, we find a negative significant correlation between return migration and Western destinations relative to Arab countries, albeit it is not significant.

We finally calculate the predicted values of the impact of return and current migration on the preference for political and social change (Table 11). Results suggest that having a returnee family member increases preference for change by over 60 percent. Confirming previous findings, this effect is due to returnees from Western countries, whilst returnees 
from non-West countries have much closer preferences for change than non-migrant households. Focusing on families with a current migrant shows that on average diaspora decreases preference for change by 20 percentage points compared to respondents with no migration experience. This time, current migrants outside the Western world drive this result.

\section{Spillover Effects of Return Migration}

In order to show the consistency of our findings, we extend the present analysis by looking at different data sources. We intend to explore whether the new political norms that return migrants bring back home expand beyond the household of origin to the local community.

First, we use the 2011 World Values Survey (WVS) of Morocco and exploit two questions: "I do not have confidence in the government" and "I am interested into politics", which proxy for political preferences. We then utilize the most current available population census carried out in 2004 to calculate the share of returnees among the population of each of the 24 available sub-regions, which we then merge into the 2011 WVS. The resulting dataset provides information on over 1,100 individuals in Morocco on both political norms and the share of returnees in each sub-region. The following OLS regression is therefore estimated in order to test the existence of spillover effects of return migration:

$$
N_{i s}=\alpha_{0}+\alpha_{1} R_{s}+\alpha_{2} C_{i s}+\epsilon_{i s}
$$

where $N_{i s}$ is our proxy of political norms for individual $i$ living in sub-region $s$, and $R_{s}$ is the share of returnees in each of the 24 sub-regions. Controls $C_{i s}$ include sex and marital status dummies, age and age squared, number of children, educational attainment, working status, as well as a dummy if individual $i$ works for the government.

Columns 1 (Dependent variable: "I do not have confidence in the government") and 2 (Dependent variable: "I am interested into politics") in Table 12 show the results of equation 10, which confirm that return migration affects political norms beyond the household of origin thanks to spillover effects to the local communities. Since the share of returnees may be endogenous, we also adopt a 2SLS estimation, where return migration is instru- 
mented by the growth rate of returnees in each sub-region $\left(R G_{s}\right)$. In particular, data on the share of returnees by sub-region $\left(R_{s}\right)$ are calculated using the 2004 and the 1994 Moroccan census. The growth rate $R G_{s}$ of returnees in each sub-region $s$ is given by:

$$
R G_{s}=\frac{R_{s}^{2004}-R_{s}^{1994}}{R_{s}^{1994}}
$$

2SLS estimation in columns 3 and 4 of Table 12 emphasizes the validity of our instrument and the robustness of our findings: political norms are indeed transferred from returnees to household members and ultimately spread by word of mouth to the local communities.

Second, we want to examine whether political and social attitudes translate into actions or outcomes. We adopt the Round 5 of the AfroBarometer, a survey that measures public attitudes on economic, political, and social matters in more than 30 African countries, carried out by the Institute for Justice and Reconciliation (IJR) in South Africa, the Ghana Center for Democratic Development, the Institute for Empirical Research in Political Economy in Benin, the Institute for Development Studies (IDS) at the University of Nairobi, and the Department of Political Science at Michigan State University.

Specifically, we focus on the survey for Morocco, which has been undertaken in 2013 on 1,200 individuals, and we exploit one question on the 2011 parliamentary election: "Did you vote in the last national election held in 2011?". It is worth noting that the demonstrations exploded during the Arab spring led King Mohammed VI to establish earlier election, to be held all around Morocco on November 25th 2011. By matching again the shares of returnees in each of the 60 localities from the 2004 Census with the AfroBarometer data, we are able to estimate the following specification:

$$
V_{i l}=\alpha_{0}+\alpha_{1} R_{l}+\alpha_{2} C_{i l}+\epsilon_{i l}
$$

where $V_{i l}$ is a dummy being 1 if individual $i$ has voted in the 2011 elections; $R_{l}$ is the share of returnees in locality $l$ where individual $i$ lives, and $C_{i l}$ are the controls, which include sex, age, age squared, rural dummy, education and employment status, as well as proxies for wealth, such as having a the shelter's roof in cement and having the main source of water inside the house. 
Remarkably, results in Table 13 shows that individuals living in areas with higher concentration of returnees are more likely to have participated in the 2011 elections. Findings are robust to the inclusion of additional controls capturing regional characteristics, such as average educational attainment, employment rate, access to water and electricity (column 2 ), as well as instrumenting the share of returnees in a given locality by the growth rate of returnees in each locality $\left(R G_{l}\right)$, as calculated above. In sum, using different databases, such as the 2011 World Value Survey, the 2013 AfroBarometer and the 1994/2004 Census, indicates that migration affects political preferences as well as behaviors.

\section{Conclusions}

Does international migration act as a driver of political and social change? We look at the interesting case of Morocco, a North-African country that has become a major emigration hub to Europe and where there have been insistent calls for political change over the last few years. We exploit a recent and unique dataset in order to test whether returnees have different political behaviors and preferences than non-migrants. Findings provide evidence that return migration has a positive impact on the preference for political and social change after controlling for the double selectivity of emigration and return migration. We further demonstrate that the positive impact of return migration is driven by returnees coming from Western countries, where they have acquired democratic political norms.

We also examine the impact of having a current migrant overseas on the attitudes of the left behind versus non-migrants. Interestingly, having a current migrant among the household members has an opposite and negative effect on the demand for political and social change, driven by migrants residing in Arab countries, where the level of political institutions and accountability is low. Importantly, we control for the destination selectivity, and find that our results are robust.

Furthermore, in order to test whether the impact of migration not only affects attitudes but also actions, we study electoral participation and find a positive and significant impact of the share of returnees in a given locality on the participation rate in the 2011 parliamentary elections. 
Overall, our findings suggest that international migration can be a driver of political and social change. However, the impact of host countries matters, as newly acquired norms and attitudes are not always "superior" to the norms at origin. This implies an eventual benefit for migration to Western countries, where the level of democracy and institutional quality is greater than in the rest of the world, and hence there is potential for positive transfer of norms from host to home countries. 


\section{Bibliography}

Asselin, Louis-Marie. 2002. Multidimensional poverty theory. Composite indicator of multidimensional poverty. Levis: Institut de Mathematique Gauss.

Batista, Catia, \& Vicente, Pedro C. 2011. Do migrants improve governance at home? Evidence from a voting experiment. World Bank Economic Review, 25(1), 77-104.

Beine, Michel, \& Sekkat, Khalid. 2013. Skilled migration and the transfer of institutional norms. IZA Journal of Migration, 2(1), 1-19.

Borjas, George, \& Bratsberg, Bernt. 1996. Who leaves? The outmigration of the foreignborn. The Review of Economics and Statistics, 78(1), 165-76.

Chauvet, Lisa, \& Mercier, Marion. 2014. Do return migrants transfer political norms to their origin country? Evidence from Mali. Journal of Comparative Economics, 42(3), $630-651$.

Chou, Meng Hsuan, \& Baygert, Nicolas. 2007. The 2006 French immigration and integration law: Europeanisation or Nicolas Sarkozy's presidential keystone? COMPAS Working Paper No. 45. Oxford: COMPAS.

de Haas, Hein. 2014. Morocco: Profile. Washington, DC: Migration Policy Institute.

de Haas, Hein, \& Fokkema, Tineke. 2010. Intra-household conflicts in migration decisionmaking: Return and pendulum migration in Morocco. Population and Development Review, 36(3), 541-561.

Docquier, Frédéric, Lodigiani, Elisabetta, Rapoport, Hillel, \& Schiff, Maurice. 2016. Emigration and democracy. Journal of Development Economics, Forthcoming.

Filmer, Deon, \& Pritchett, Lant H. 2001. Estimating wealth effects without expenditure data - Or tears: An application to educational enrollments in states of India. Demography, 38(1), 115-132.

Gubert, Flore, \& Nordman, Christophe J. 2011. Return migration and small enterprise development in the Maghreb. In Diaspora for Development in Africa. Washington, DC: World Bank. 
Hamdouch, Bachir, \& Mghari, M. 2014. Impact de la migration internationale sur le developpement au Maroc: Resultats de l'enquete de 2013. IOM and MCMREAM.

Hamdouch, Bachir, \& Wahba, Jackline. 2015. Return migration and entrepreneurship in Morocco. Middle East Development Journal, 7(2), 129-148.

Khachani, Mohamed. 2012. Migrations et competences au Maroc. Projet de Rapport ETF, AMERM, ENP-S-CSP Working Paper.

Migration Policy Centre. 2013. MPC - Migration Profile: Libya. Fiesole: European University Institute.

Omar Mahmoud, Toman, Rapoport, Hillel, Steinmayr, Andreas, \& Trebesch, Christoph. 2014. The effect of labor migration on the diffusion of democracy: Evidence from a former Soviet Republic. IZA Discussion Paper No. 7980.

Özden, Çağlar, Parsons, Christopher R, Schiff, Maurice, \& Walmsley, Terrie L. 2011. Where on earth is everybody? The evolution of global bilateral migration 1960-2000. World Bank Economic Review, 25(1), 12-56.

Pfutze, Tobias. 2012. Does migration promote democratization? Evidence from the Mexican transition. Journal of Comparative Economics, 40(2), 159-175.

Roodman, David. 2011. Estimating fully observed recursive mixed-process models with cmp. Stata Journal, 11(2), 159-206.

Spilimbergo, Antonio. 2009. Democracy and foreign education. American Economic Review, 528-543.

Tuccio, Michele, \& Wahba, Jackline. 2015. Can I have permission to leave the house? Return migration and the transfer of gender norms. IZA Discussion Paper No. 9216.

Wahba, Jackline. 2015. Selection, selection, selection: The impact of return migration. Journal of Population Economics, 28, 535-563. 
Table 1: Characteristics of migrants

\begin{tabular}{lrr}
\hline & Return migrant & Current migrant \\
\hline Destination (\%) & 14.67 & \\
Spain & 34.22 & 20.75 \\
France & 28.44 & 30.30 \\
Italy & 7.99 & 22.72 \\
Other European countries & 0.89 & 15.80 \\
USA & 1.33 & 4.61 \\
Canada & 11.09 & 1.98 \\
Arab countries & 0.44 & 3.30 \\
African countries & 0.89 & 0.22 \\
Other countries & & 0.33 \\
Educational level (\%) & 0.41 & \\
No education & 0.17 & 0.11 \\
Primary education & 0.20 & 0.22 \\
College & 0.15 & 0.25 \\
Secondary education & 0.06 & 0.29 \\
Superior education & & 0.12 \\
Duration of migration & 11.32 & \\
Years & & 11.51 \\
\hline
\end{tabular}

Data source: IIIMD, 2013. 
Table 2: Characteristics of respondents from households with no migrants, returnees and current migrants

\begin{tabular}{lccc} 
& Without migrant & With returnee & With current \\
\hline Political and social change (\%) & & & \\
Political administration & 0.24 & 0.32 & 0.29 \\
Civil engagement & 0.92 & $0.86^{*}$ & 0.89 \\
Traditional lifestyle & 0.06 & 0.04 & 0.04 \\
Gender equality & 0.89 & 0.89 & 0.89 \\
Social cohesion & 0.94 & 0.95 & 0.94 \\
Composite index (PCA) & 0.61 & 0.61 & 0.61 \\
Composite index (MCA) & 0.8 & 0.79 & 0.79 \\
Composite index (equal weights) & 0.61 & 0.61 & 0.61 \\
Educational level (\%) & & & \\
No education & 0.35 & 0.40 & 0.40 \\
Primary education & 0.23 & 0.18 & 0.20 \\
College & 0.15 & 0.18 & 0.12 \\
Secondary education & 0.18 & 0.19 & 0.20 \\
Superior education & 0.09 & 0.06 & 0.09 \\
Individual characteristics & & & \\
Female & 0.29 & $0.19^{*}$ & $0.43^{* * *}$ \\
Age & 48.5 & $54.44^{* * *}$ & $53.79^{* * *}$ \\
Married & 0.81 & 0.79 & $0.69^{* * *}$ \\
Rural areas & 0.15 & 0.16 & 0.12 \\
Metropolis & 0.23 & 0.19 & 0.22 \\
Employment status & 0.54 & 0.45 & $0.34^{* * *}$ \\
Head of household & 0.73 & 0.74 & 0.69 \\
Accommodation owner & 0.63 & $0.89^{* * *}$ & $0.80^{* * *}$ \\
\hline$N$ & 216 & 225 & 915 \\
\hline Notes. (I) T-test for different means, where the control group is always those individuals with no migrant
\end{tabular}

in the houshold. (II) ***,**, and * respresent $1 \%, 5 \%$ and $10 \%$ significance levels, respectively-(III) Data source: IIIMD, 2013. 
Table 3: Return migration and the preference for political and social change

\begin{tabular}{|c|c|c|c|}
\hline & (1) & $(2)$ & (3) \\
\hline $\begin{array}{l}\text { Political and Social Change } \\
\text { return migration }\end{array}$ & $\begin{array}{l}-0.004 \\
(0.26)\end{array}$ & $\begin{array}{c}0.059 \\
(2.52)^{* *}\end{array}$ & $\begin{array}{c}0.093 \\
(2.72)^{* * *}\end{array}$ \\
\hline $\begin{array}{l}\text { Probability of Return Migration } \\
\text { shock }\end{array}$ & & $\begin{array}{c}0.833 \\
(33.68)^{* * *}\end{array}$ & $\begin{array}{c}0.792 \\
(27.28)^{* * *}\end{array}$ \\
\hline $\begin{array}{l}\text { Probability of Emigration } \\
\text { attractiveness }\end{array}$ & & & $\begin{array}{c}0.050 \\
(2.84)^{* * *}\end{array}$ \\
\hline $\begin{array}{l}\text { sigma_1 } \\
\text { sigma_2 }\end{array}$ & & $\begin{array}{c}-1.163 \\
(31.30)^{* * *}\end{array}$ & $\begin{array}{c}-1.160 \\
(30.99)^{* * *} \\
-0.981 \\
(29.59)^{* * *}\end{array}$ \\
\hline rho_12 & & $\begin{array}{c}-0.181 \\
(2.79)^{* * *}\end{array}$ & $\begin{array}{c}-0.212 \\
(2.93)^{* * *}\end{array}$ \\
\hline rho_13 & & & $\begin{array}{l}-0.169 \\
(1.78)^{*}\end{array}$ \\
\hline rho_23 & & & $\begin{array}{c}0.292 \\
(6.46)^{* * *}\end{array}$ \\
\hline $\mathrm{N}$ & 441 & 441 & 441 \\
\hline
\end{tabular}

Notes. (I) ${ }^{* * *},{ }^{* *}$, and $*$ respresent $1 \%, 5 \%$ and $10 \%$ significance levels, respectively. (II) All specifications are weighted by the sampling weights provided in the dataset, with robust standard errors. (III) The selection equations are based on full sample of 1,524 observations. (IV) Data source: IIIMD, 2013. 
Table 4: Return migration and the preference for change using different weighting techniques

\begin{tabular}{|c|c|c|c|c|c|c|}
\hline & (1) & (2) & (3) & (4) & (5) & (6) \\
\hline $\begin{array}{l}\text { Political and Social Change } \\
\text { return migration }\end{array}$ & $\begin{array}{l}0.004 \\
(0.21)\end{array}$ & $\begin{array}{c}\boldsymbol{m} \boldsymbol{c a} \boldsymbol{a} \\
0.050 \\
(1.88)^{*}\end{array}$ & $\begin{array}{c}0.072 \\
(2.24)^{* *}\end{array}$ & $\begin{array}{l}0.005 \\
(0.33)\end{array}$ & $\begin{array}{c}\text { equal } \\
0.055 \\
(2.20)^{* *}\end{array}$ & $\begin{array}{c}0.079 \\
(2.60)^{* * *}\end{array}$ \\
\hline $\begin{array}{l}\text { Probability of Return Migration } \\
\text { shock }\end{array}$ & & $\begin{array}{c}0.833 \\
(33.68)^{* * *}\end{array}$ & $\begin{array}{c}0.792 \\
(27.30)^{* * *}\end{array}$ & & $\begin{array}{c}0.833 \\
(33.68)^{* * *}\end{array}$ & $\begin{array}{c}0.792 \\
(27.29)^{* * *}\end{array}$ \\
\hline $\begin{array}{l}\text { Probability of Emigration } \\
\text { attractiveness }\end{array}$ & & & $\begin{array}{c}0.050 \\
(2.88)^{* * *}\end{array}$ & & & $\begin{array}{c}0.050 \\
(2.87)^{* * *}\end{array}$ \\
\hline $\begin{array}{l}\text { sigma_1 } \\
\text { sigma_2 }\end{array}$ & & $\begin{array}{c}-1.163 \\
(31.30)^{* * *}\end{array}$ & $\begin{array}{c}-1.160 \\
(30.99)^{* * *} \\
-0.981 \\
(29.59)^{* * *}\end{array}$ & & $\begin{array}{c}-1.163 \\
(31.30)^{* * *}\end{array}$ & $\begin{array}{c}-1.160 \\
(30.99)^{* * *} \\
-0.981 \\
(29.60)^{* * *}\end{array}$ \\
\hline rho_12 & & $\begin{array}{l}-0.123 \\
(1.87)^{*}\end{array}$ & $\begin{array}{l}-0.143 \\
(1.99)^{* *}\end{array}$ & & $\begin{array}{l}-0.146 \\
(2.20)^{* *}\end{array}$ & $\begin{array}{l}-0.171 \\
(2.38)^{* *}\end{array}$ \\
\hline rho_13 & & & $\begin{array}{r}-0.106 \\
(1.38)\end{array}$ & & & $\begin{array}{l}-0.132 \\
(1.66)^{*}\end{array}$ \\
\hline rho_23 & & & $\begin{array}{c}0.292 \\
(6.45)^{* * *} \\
\end{array}$ & & & $\begin{array}{c}0.292 \\
(6.47)^{* * *} \\
\end{array}$ \\
\hline $\mathrm{N}$ & 441 & 441 & 441 & 441 & 441 & 441 \\
\hline
\end{tabular}

Notes. (I) ***, **, and ${ }^{*}$ respresent $1 \%, 5 \%$ and 10\% significance levels, respectively. (II) All specifications are weighted by the sampling weights provided in the dataset, with robust standard errors. (III) The selection equations are based on full sample of 1,524 observations. (IV) Data source: IIIMD, 2013. 
Table 5: Return migration and the preference for change using a different instrument for the selection into emigration

\begin{tabular}{lccc}
\hline & $(1)$ & $(2)$ & $(3)$ \\
\hline Political and Social Change & pca & mca & equal \\
return migration & 0.093 & 0.072 & 0.079 \\
& $(2.72)^{* * *}$ & $(2.23)^{* *}$ & $(2.59)^{* * *}$ \\
\hline Probability of Return Migration & & & \\
shock & 0.792 & 0.792 & 0.792 \\
& $(27.14)^{* * *}$ & $(27.16)^{* * *}$ & $(27.14)^{* * *}$ \\
\hline Probability of Emigration & & & \\
attractiveness (FRA, CAN, LBY) & 0.048 & 0.049 & 0.048 \\
& $(2.81)^{* * *}$ & $(2.85)^{* * *}$ & $(2.83)^{* * *}$ \\
\hline sigma_1 & -1.160 & -1.160 & -1.160 \\
& $(30.99)^{* * *}$ & $(30.99)^{* * *}$ & $(31.00)^{* * *}$ \\
sigma_2 & -0.981 & -0.981 & -0.981 \\
& $(29.63)^{* * *}$ & $(29.63)^{* * *}$ & $(29.64)^{* * *}$ \\
rho_12 & -0.212 & -0.143 & -0.171 \\
& $(2.93)^{* * *}$ & $(1.99)^{* *}$ & $(2.38)^{* *}$ \\
rho_13 & -0.170 & -0.107 & -0.131 \\
& $(1.78)^{*}$ & $(1.37)$ & $(1.65)^{*}$ \\
rho_23 & 0.290 & 0.291 & 0.290 \\
& $(6.40)^{* * *}$ & $(6.40)^{* * *}$ & $(6.41)^{* * *}$ \\
\hline $\mathrm{N}$ & 441 & 441 & 441 \\
\hline
\end{tabular}

Notes. (I) $* * *, * *$, and $*$ respresent $1 \%, 5 \%$ and $10 \%$ significance levels, respectively. (II) All specifications are weighted by the sampling weights provided in the dataset, with robust standard errors. (III) The selection equations are based on full sample of 1,524 observations. (IV) Data source: IIIMD, 2013. 
Table 6: Return migration and the preference for change using single variables

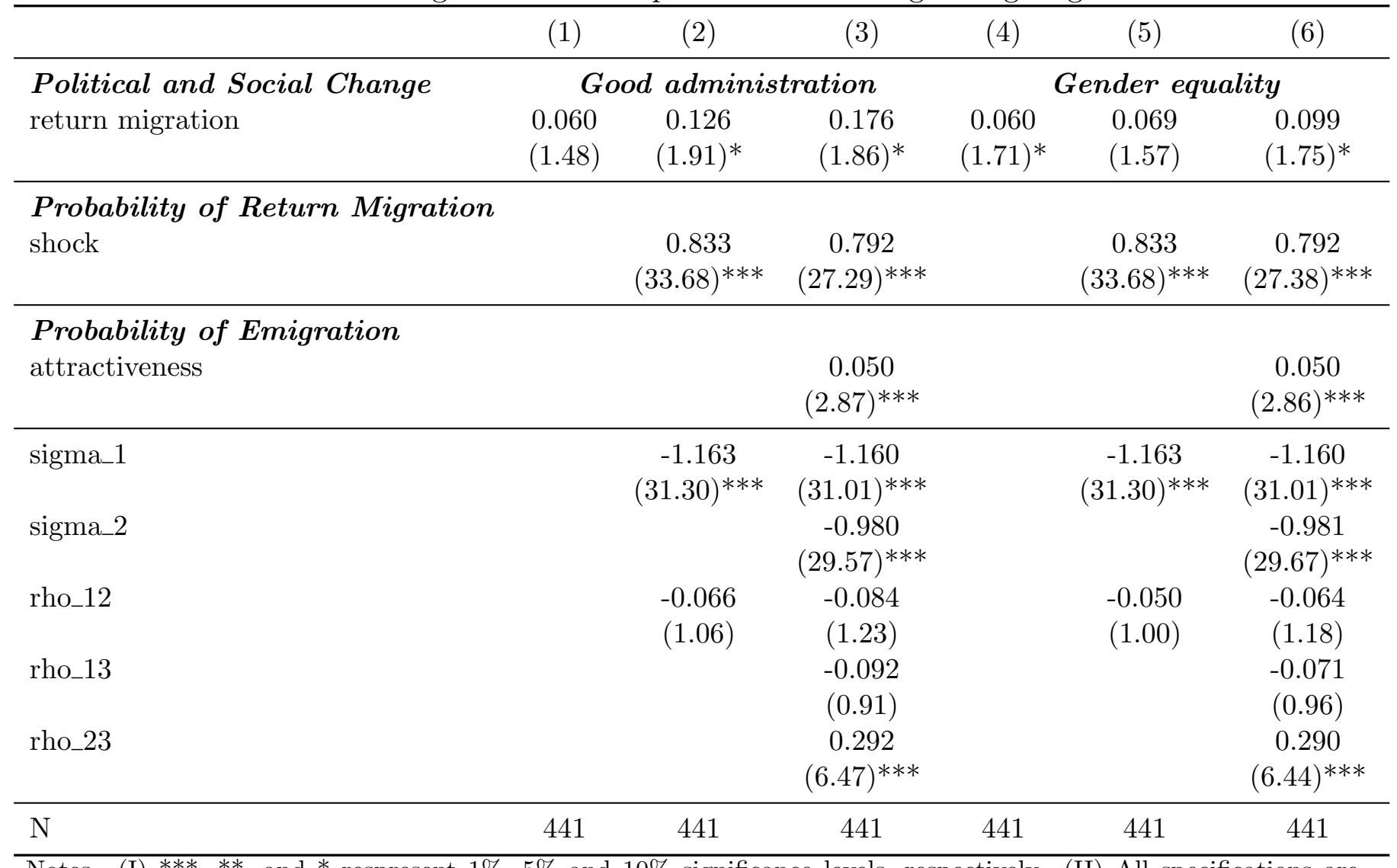

Notes. (I) ${ }^{* * *},{ }^{* *}$, and ${ }^{*}$ respresent $1 \%, 5 \%$ and $10 \%$ significance levels, respectively. (II) All specifications are weighted by the sampling weights provided in the dataset, with robust standard errors. (III) The selection equations are based on full sample of 1,524 observations. (IV) Data source: IIIMD, 2013. 
Table 7: Return migration by destination and the preference for change

\begin{tabular}{|c|c|c|c|c|}
\hline & (1) & (2) & (3) & (4) \\
\hline $\begin{array}{l}\text { Political and Social Change } \\
\text { return migration }\end{array}$ & $\begin{array}{c}\text { Uncon } \\
\text { West } \\
0.074 \\
(2.71)^{* * *}\end{array}$ & $\begin{array}{c}\text { ditional } \\
\text { non- } \boldsymbol{W e s t} \\
-0.044 \\
(1.15)\end{array}$ & $\begin{array}{c}\quad \text { Cond } \\
\text { West } \\
0.067 \\
(2.05)^{* *}\end{array}$ & $\begin{array}{l}\text { tional } \\
\qquad \begin{array}{l}\text { West } \\
0.068 \\
(2.08)^{* *}\end{array}\end{array}$ \\
\hline $\begin{array}{l}\text { Probability of Return Migration } \\
\text { shock }\end{array}$ & $\begin{array}{c}0.796 \\
(28.20)^{* * *}\end{array}$ & $\begin{array}{c}0.798 \\
(28.23)^{* * *}\end{array}$ & $\begin{array}{c}0.792 \\
(27.41)^{* * *}\end{array}$ & $\begin{array}{c}0.792 \\
(27.45)^{* * *}\end{array}$ \\
\hline $\begin{array}{l}\text { Probability of Emigration } \\
\text { attractiveness }\end{array}$ & $\begin{array}{c}0.050 \\
(2.85)^{* * *}\end{array}$ & $\begin{array}{c}0.051 \\
(2.89)^{* * *}\end{array}$ & $\begin{array}{c}0.051 \\
(2.91)^{* * *}\end{array}$ & $\begin{array}{c}0.051 \\
(2.91)^{* * *}\end{array}$ \\
\hline sigma_1 & $\begin{array}{c}-1.160 \\
(31.02)^{* * *}\end{array}$ & $\begin{array}{c}-1.160 \\
(31.03)^{* * *}\end{array}$ & $\begin{array}{c}-1.160 \\
(30.97)^{* * *}\end{array}$ & $\begin{array}{c}-1.160 \\
(30.98)^{* * *}\end{array}$ \\
\hline sigma_2 & $\begin{array}{c}-0.981 \\
(29.62)^{* * *}\end{array}$ & $\begin{array}{c}-0.981 \\
(29.63) * * *\end{array}$ & $\begin{array}{c}-0.981 \\
(29.59)^{* * *}\end{array}$ & $\begin{array}{c}-0.980 \\
(29.60)^{* * *}\end{array}$ \\
\hline rho_12 & $\begin{array}{c}-0.170 \\
(2.90)^{* * *}\end{array}$ & $\begin{array}{r}-0.068 \\
(1.43)\end{array}$ & $\begin{array}{c}-0.243 \\
(2.92)^{* * *}\end{array}$ & $\begin{array}{c}-0.248 \\
(2.96)^{* * *}\end{array}$ \\
\hline rho_13 & $\begin{array}{r}-0.117 \\
(1.43)\end{array}$ & $\begin{array}{l}0.029 \\
(0.47)\end{array}$ & $\begin{array}{r}-0.375 \\
(1.47)\end{array}$ & $\begin{array}{r}-0.341 \\
(1.38)\end{array}$ \\
\hline rho_23 & $\begin{array}{c}0.290 \\
(6.47)^{* * *}\end{array}$ & $\begin{array}{c}0.290 \\
(6.50)^{* * *}\end{array}$ & $\begin{array}{c}0.291 \\
(6.47)^{* * *}\end{array}$ & $\begin{array}{c}0.293 \\
(6.52)^{* * *}\end{array}$ \\
\hline $\mathrm{N}$ & 441 & 441 & 225 & 225 \\
\hline
\end{tabular}

Notes. (I) ${ }^{* * *},{ }^{* *}$, and ${ }^{*}$ respresent $1 \%, 5 \%$ and $10 \%$ significance levels, respectively. (II) All specifications are weighted by the sampling weights provided in the dataset, with robust standard errors. (III) The selection equations are based on full sample of 1,524 observations. (IV) Data source: IIIMD, 2013. 
Table 8: Current migration and the preference for political and social change

\begin{tabular}{lccccccc}
\hline & $(1)$ & $(2)$ & $(3)$ & $(4)$ & $(5)$ & $(6)$ & $(7)$ \\
\hline Political and Social Change & $\boldsymbol{p c a}$ & $\boldsymbol{p c a}$ & $\boldsymbol{m c a}$ & $\boldsymbol{e q u a l}$ & $\boldsymbol{p c a}$ & $\boldsymbol{p c a}$ & $\boldsymbol{p c a}$ \\
current migration & -0.036 & -0.140 & -0.158 & -0.084 & -0.134 & -0.183 & -0.179 \\
& $(1.67)^{*}$ & $(2.66)^{* * *}$ & $(2.58)^{* * *}$ & $(1.88)^{*}$ & $(2.20)^{* *}$ & $(2.61)^{* * *}$ & $(2.49)^{* *}$ \\
\hline Probability of Emigration & & & & & & & \\
attractiveness & & 0.073 & 0.070 & 0.071 & 0.058 & 0.089 & 0.102 \\
& & $(3.33)^{* * *}$ & $(3.20)^{* * *}$ & $(3.10)^{* * *}$ & $(2.77)^{* * *}$ & $(3.47)^{* * *}$ & $(3.52)^{* * *}$ \\
\hline sigma_1 & & -0.908 & -0.908 & -0.908 & -0.954 & -0.881 & -0.879 \\
& & $(28.55)^{* * *}$ & $(28.55)^{* * *}$ & $(28.53)^{* * *}$ & $(26.11)^{* * *}$ & $(22.60)^{* * *}$ & $(18.64)^{* * *}$ \\
rho_12 & & 0.364 & 0.381 & 0.224 & 0.303 & 0.517 & 0.527 \\
& & $(2.37)^{* *}$ & $(2.74)^{* * *}$ & $(1.69)^{*}$ & $(1.75)^{*}$ & $(2.62)^{* * *}$ & $(2.50)^{* *}$ \\
\hline $\mathrm{N}$ & 448 & 448 & 448 & 448 & 510 & 300 & 228
\end{tabular}

Notes. (I) ${ }^{* * *}{ }^{* *}$, and $*$ respresent $1 \%, 5 \%$ and $10 \%$ significance levels, respectively. (II) All specifications are weighted by the sampling weights provided in the dataset, with robust standard errors. (III) The selection equations are based on full sample of 732 observations. (IV) Data source: IIIMD, 2013. 
Table 9: Current migration by destination and the preference for change

\begin{tabular}{|c|c|c|c|}
\hline & (1) & $(2)$ & $(3)$ \\
\hline \multirow{4}{*}{$\begin{array}{l}\text { Political and Social Change } \\
\text { current migration }\end{array}$} & \multicolumn{2}{|c|}{ Unconditional } & Conditional \\
\hline & West & non-West & West \\
\hline & 0.008 & -0.095 & 0.092 \\
\hline & $(0.16)$ & $(2.43)^{* *}$ & $(2.61)^{* * *}$ \\
\hline \multirow{3}{*}{$\begin{array}{l}\text { Probability of Emigration } \\
\text { attractiveness }\end{array}$} & & & \\
\hline & 0.056 & 0.057 & 0.059 \\
\hline & $(2.59)^{* * *}$ & $(2.67)^{* * *}$ & $(2.78)^{* * *}$ \\
\hline \multirow[t]{2}{*}{ sigma_1 } & -1.013 & -1.013 & -1.013 \\
\hline & $(31.45)^{* * *}$ & $(31.45)^{* * *}$ & $(31.47)^{* * *}$ \\
\hline \multirow[t]{2}{*}{ rho_12 } & -0.068 & -0.034 & 0.112 \\
\hline & $(0.54)$ & $(0.60)$ & $(0.45)$ \\
\hline $\mathrm{N}$ & 448 & 448 & 319 \\
\hline
\end{tabular}

Notes. (I) $* * *, * *$, and $*$ respresent $1 \%, 5 \%$ and $10 \%$ significance levels, respectively. (II) All specifications are weighted by the sampling weights provided in the dataset, with robust standard errors. (III) The selection equations are based on full sample of 732 observations. (IV) Data source: IIIMD, 2013. 


\begin{tabular}{|c|c|c|}
\hline $\begin{array}{l}\text { Political and Social Change } \\
\text { return migration } \\
\text { current migration }\end{array}$ & $\begin{array}{c}0.055 \\
(2.01)^{* *}\end{array}$ & $\begin{array}{l}-0.069 \\
(2.02)^{* *}\end{array}$ \\
\hline $\begin{array}{l}\text { Probability of Return Migration } \\
\text { shock }\end{array}$ & $\begin{array}{c}0.823 \\
(31.24)^{* * *}\end{array}$ & \\
\hline $\begin{array}{l}\text { Probability of Emigration } \\
\text { attractiveness }\end{array}$ & $\begin{array}{c}4.558 \\
(5.63)^{* * *}\end{array}$ & $\begin{array}{c}4.617 \\
(5.74)^{* * *}\end{array}$ \\
\hline $\begin{array}{l}\text { Destination selection } \\
\text { growth france/libya }\end{array}$ & $\begin{array}{c}0.000 \\
(1.76)^{*}\end{array}$ & $\begin{array}{c}0.000 \\
(1.74)^{*}\end{array}$ \\
\hline sigma_1 & $\begin{array}{c}-1.163 \\
(31.27)^{* * *}\end{array}$ & $\begin{array}{c}-1.045 \\
(26.47)^{* * *}\end{array}$ \\
\hline sigma_2 & $\begin{array}{l}-1.045 \\
(26.48)^{* * *}\end{array}$ & $\begin{array}{c}-1.152 \\
(8.56)^{* * *}\end{array}$ \\
\hline sigma_3 & $\begin{array}{c}-1.171 \\
(8.18)^{* * *}\end{array}$ & \\
\hline rho_12 & $\begin{array}{c}-0.181 \\
(2.70)^{* * *}\end{array}$ & $\begin{array}{l}0.075 \\
(0.80)\end{array}$ \\
\hline rho_13 & $\begin{array}{l}0.011 \\
(0.16)\end{array}$ & $\begin{array}{l}0.124 \\
(1.43)\end{array}$ \\
\hline rho_14 & $\begin{array}{c}0.122 \\
(1.66)^{*}\end{array}$ & \\
\hline rho_23 & $\begin{array}{c}0.102 \\
(2.29)^{* *}\end{array}$ & $\begin{array}{c}1.219 \\
(4.89)^{* * *}\end{array}$ \\
\hline rho_24 & $\begin{array}{r}-0.011 \\
(0.17)\end{array}$ & \\
\hline rho_34 & $\begin{array}{c}1.179 \\
(4.32)^{* * *}\end{array}$ & \\
\hline $\mathrm{N}$ & 441 & 448 \\
\hline
\end{tabular}

Notes. (I) ${ }^{* * *}, * *$, and $*$ respresent $1 \%, 5 \%$ and $10 \%$ significance levels, respectively. (II) All specifications are weighted by the sampling weights provided in the dataset, with robust standard errors. (III) The selection equations are based on full sample of 1,524 observations. (IV) Data source: IIIMD, 2013. 
Table 11: Average predicted values

\begin{tabular}{|c|c|c|c|c|}
\hline & With migrant & Without migrant & Difference $(\%)$ & P-value \\
\hline \multicolumn{5}{|c|}{ Preference for change - Return migration } \\
\hline Whole sample & 0.649 & 0.559 & 0.16 & 0.000 \\
\hline Returnees from the West & 0.641 & 0.559 & 0.15 & 0.000 \\
\hline Returnees from the non-West & 0.572 & 0.559 & 0.02 & 0.005 \\
\hline \multicolumn{5}{|c|}{ Preference for change - Current migration } \\
\hline Whole sample & 0.450 & 0.559 & -0.20 & 0.000 \\
\hline Current migrants in the West & 0.557 & 0.559 & 0.00 & 0.000 \\
\hline Current migrants in the non-West & 0.464 & 0.559 & -0.17 & 0.003 \\
\hline
\end{tabular}

Notes. (I) P-value reports the results of a t test of Ho: Migration=Non-migrants. (II) Values are weighted by the sampling weights provided in the dataset. (III) Data source: IIIMD, 2013. 
Table 12: Spillover effects of return migration on political norms

\begin{tabular}{|c|c|c|c|c|}
\hline & (1) & $(2)$ & $(3)$ & (4) \\
\hline \multicolumn{5}{|c|}{ Panel A: Second stage } \\
\hline share of returnees & $\begin{array}{c}7.787 \\
(2.58)^{* *}\end{array}$ & $\begin{array}{c}3.776 \\
(1.68)^{*}\end{array}$ & $\begin{array}{c}57.279 \\
(2.34)^{* *}\end{array}$ & $\begin{array}{l}26.109 \\
(1.80)^{*}\end{array}$ \\
\hline \multicolumn{5}{|c|}{ Panel B: First stage } \\
\hline return migration change & & & $\begin{array}{c}0.002 \\
(5.67)^{* * *}\end{array}$ & $\begin{array}{c}0.002 \\
(5.63)^{* * *}\end{array}$ \\
\hline $\mathrm{R} 2$ & 0.06 & 0.18 & & \\
\hline F-Stat & & & 32.11 & 31.67 \\
\hline $\mathrm{N}$ & 1,073 & 1,155 & 1,073 & 1,155 \\
\hline
\end{tabular}

Notes. (I) Dep.var. in columns 1 and 3 is "I do not have confidence in the government", whilst dep. var. in columns 2 and 4 is "I am interested into politics". (II) $* * *, * *$, and $*$ respresent $1 \%, 5 \%$ and $10 \%$ significance levels, respectively. (III) All specifications are weighted by the sampling weights provided in the datasets, with robust standard errors. (IV) Data source: World Values Survey (WVS), 2011 \& Census, 2004. 
Table 13: Spillover effects of return migration on political outcomes

\begin{tabular}{|c|c|c|c|}
\hline & (1) & $(2)$ & $(3)$ \\
\hline \multicolumn{4}{|c|}{ Panel A: Second stage } \\
\hline share of returnees & $\begin{array}{c}8.213 \\
(1.80)^{*}\end{array}$ & $\begin{array}{c}21.786 \\
(3.08)^{* * *}\end{array}$ & $\begin{array}{c}100.490 \\
(1.72)^{*}\end{array}$ \\
\hline \multicolumn{4}{|c|}{ Panel B: First stage } \\
\hline \multicolumn{3}{|c|}{ return migration change } & $\begin{array}{c}0.001 \\
(4.26)^{* * *}\end{array}$ \\
\hline Regional controls & No & Yes & Yes \\
\hline $\mathrm{R} 2$ & 0.11 & 0.13 & \\
\hline F-Stat & & & 18.17 \\
\hline $\mathrm{N}$ & 1,200 & 1,200 & 1,200 \\
\hline
\end{tabular}

Notes. (I) Dep.var. is a dummy being 1 if the individual has participated in the 2011 national elections. (II) ***,**, and * respresent $1 \%, 5 \%$ and $10 \%$ significance levels, respectively. (III) All specifications are weighted by the sampling weights provided in the datasets, with robust standard errors. (IV) Data source: AfroBarometer, 2013 \& Census, 2004. 


\section{Appendix}

Table A1: Variables included in the composite index and respective weights

\begin{tabular}{|c|c|c|c|c|}
\hline Variable & Categories & EQUAL & PCA & MCA \\
\hline \multirow{2}{*}{ I am not happy on how Morocco is administered } & Agree & 0.20 & 0.2947 & 0.209 \\
\hline & Disagree & & & -0.083 \\
\hline \multirow[t]{2}{*}{ I do not think we should defend the traditional lifestyle in Morocco } & Agree & 0.20 & 0.0966 & 0.200 \\
\hline & Disagree & & & -0.009 \\
\hline \multirow[t]{2}{*}{ We need to make more effort so that men and women are treated equally } & Agree & 0.20 & 0.5371 & 0.083 \\
\hline & Disagree & & & -0.693 \\
\hline \multirow[t]{2}{*}{ We need to make more effort so that everybody is treated equally } & Agree & 0.20 & 0.5571 & 0.062 \\
\hline & Disagree & & & -0.997 \\
\hline \multirow[t]{2}{*}{ I think people should be more involved in the decision-making process } & Agree & 0.20 & 0.5523 & 0.707 \\
\hline & Disagree & & & -0.086 \\
\hline
\end{tabular}

Data source: IIIMD, 2013 
Table A2: Robustness check - Reference year for attractiveness

\begin{tabular}{|c|c|c|c|c|c|c|}
\hline & $\begin{array}{c}(1) \\
\text { Age }=25\end{array}$ & $\begin{array}{c}(2) \\
\text { Age }=26\end{array}$ & $\begin{array}{c}(3) \\
\text { Age }=27\end{array}$ & $\begin{array}{c}(4) \\
\text { Age }=28\end{array}$ & $\begin{array}{c}(5) \\
\text { Age }=29\end{array}$ & $\begin{array}{c}(6) \\
\text { Age }=30\end{array}$ \\
\hline $\begin{array}{l}\text { Political and Social Change } \\
\text { return migration }\end{array}$ & $\begin{array}{c}0.102 \\
(3.01)^{* * *}\end{array}$ & $\begin{array}{c}0.089 \\
(2.56)^{* *}\end{array}$ & $\begin{array}{c}0.109 \\
(2.72)^{* * *}\end{array}$ & $\begin{array}{c}0.113 \\
(2.91)^{* * *}\end{array}$ & $\begin{array}{c}0.117 \\
(3.01)^{* * *}\end{array}$ & $\begin{array}{c}0.113 \\
(3.09)^{* * *}\end{array}$ \\
\hline $\begin{array}{l}\text { Probability of Return Migration } \\
\text { shock }\end{array}$ & $\begin{array}{c}0.792 \\
(27.11)^{* * *}\end{array}$ & $\begin{array}{c}0.790 \\
(26.91)^{* * *}\end{array}$ & $\begin{array}{c}0.785 \\
(26.09)^{* * *}\end{array}$ & $\begin{array}{c}0.784 \\
(25.90)^{* * *}\end{array}$ & $\begin{array}{c}0.783 \\
(25.90)^{* * *}\end{array}$ & $\begin{array}{c}0.783 \\
(25.89)^{* * *}\end{array}$ \\
\hline $\begin{array}{l}\text { Probability of Emigration } \\
\text { attractiveness }\end{array}$ & $\begin{array}{c}0.049 \\
(2.88)^{* * *}\end{array}$ & $\begin{array}{c}0.044 \\
(2.40)^{* *}\end{array}$ & $\begin{array}{l}0.034 \\
(1.58)\end{array}$ & $\begin{array}{c}0.035 \\
(1.85)^{*}\end{array}$ & $\begin{array}{c}0.047 \\
(2.46)^{* *}\end{array}$ & $\begin{array}{c}0.045 \\
(2.29)^{* *}\end{array}$ \\
\hline sigma_1 & $\begin{array}{c}-1.959 \\
(41.11)^{* * *}\end{array}$ & $\begin{array}{c}-1.963 \\
(41.50) * * *\end{array}$ & $\begin{array}{c}-1.956 \\
(40.53)^{* * *}\end{array}$ & $\begin{array}{c}-1.954 \\
(40.61)^{* * *}\end{array}$ & $\begin{array}{c}-1.952 \\
(40.39)^{* * *}\end{array}$ & $\begin{array}{c}-1.954 \\
(40.92)^{* * *}\end{array}$ \\
\hline sigma_2 & $\begin{array}{c}-1.160 \\
(30.99)^{* * *}\end{array}$ & $\begin{array}{c}-1.160 \\
(31.00)^{* * *}\end{array}$ & $\begin{array}{c}-1.160 \\
(30.96)^{* * *}\end{array}$ & $\begin{array}{c}-1.160 \\
(30.96)^{* * *}\end{array}$ & $\begin{array}{c}-1.160 \\
(30.95)^{* * *}\end{array}$ & $\begin{array}{c}-1.160 \\
(30.96)^{* * *}\end{array}$ \\
\hline rho_12 & $\begin{array}{c}-0.218 \\
(3.00)^{* * *}\end{array}$ & $\begin{array}{c}-0.209 \\
(2.86)^{* * *}\end{array}$ & $\begin{array}{c}-0.224 \\
(3.00)^{* * *}\end{array}$ & $\begin{array}{c}-0.228 \\
(3.07)^{* * *}\end{array}$ & $\begin{array}{c}-0.231 \\
(3.12)^{* * *}\end{array}$ & $\begin{array}{c}-0.230 \\
(3.10)^{* * *}\end{array}$ \\
\hline rho_13 & $\begin{array}{c}-0.206 \\
(2.19)^{* *}\end{array}$ & $\begin{array}{l}-0.154 \\
(1.58)\end{array}$ & $\begin{array}{l}-0.229 \\
(1.90)^{*}\end{array}$ & $\begin{array}{c}-0.242 \\
(2.10)^{* *}\end{array}$ & $\begin{array}{c}-0.257 \\
(2.23)^{* *}\end{array}$ & $\begin{array}{c}-0.247 \\
(2.29)^{* *}\end{array}$ \\
\hline rho_23 & $\begin{array}{c}0.291 \\
(6.06)^{* * *}\end{array}$ & $\begin{array}{c}0.299 \\
(6.34)^{* * *}\end{array}$ & $\begin{array}{c}0.319 \\
(6.80)^{* * *}\end{array}$ & $\begin{array}{c}0.323 \\
(6.88)^{* * *}\end{array}$ & $\begin{array}{c}0.324 \\
(6.92)^{* * *}\end{array}$ & $\begin{array}{c}0.322 \\
(6.81)^{* * *}\end{array}$ \\
\hline $\mathrm{N}$ & 441 & 441 & 441 & 441 & 441 & 441 \\
\hline
\end{tabular}

Notes. (I) ${ }^{* * *},{ }^{* *}$, and ${ }^{*}$ respresent $1 \%, 5 \%$ and $10 \%$ significance levels, respectively. (II) All specifications are weighted by the sampling weights provided in the dataset, with robust standard errors. (III) The selection equations are based on full sample of 1,524 observations. (IV) Data source: IIIMD, 2013. 
Figure A1: Emigrants by year and shocks

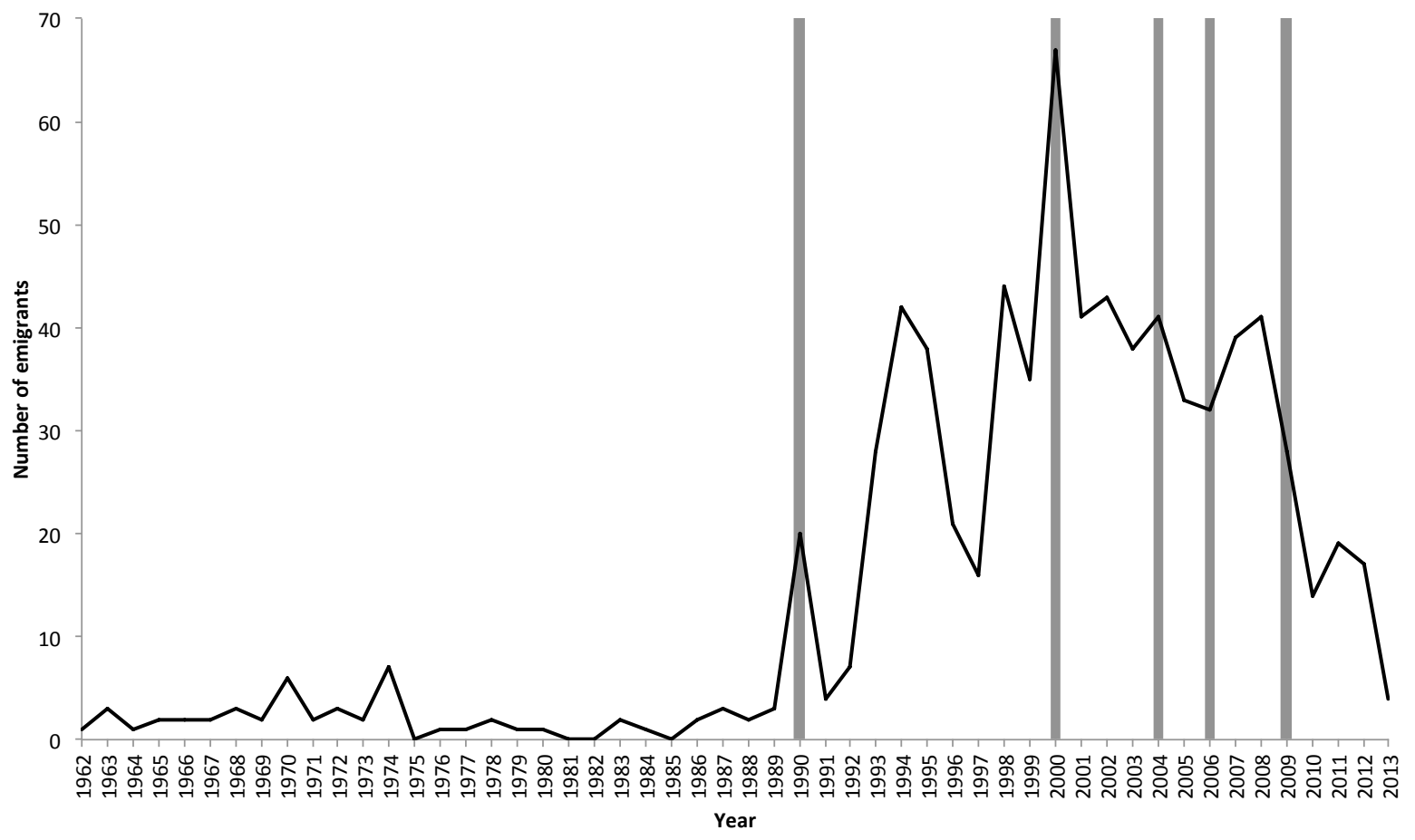


Table A3: Selection into destination

\begin{tabular}{lccccc}
\hline & $(1)$ & $(2)$ & $(3)$ & $(4)$ & $(5)$ \\
\hline Migrated to improve lifestyle & -0.043 & & & -0.033 & \\
& $(1.11)$ & & & $(0.84)$ & \\
Happy to have lived abroad & & -0.004 & & 0.010 & \\
& & $(0.07)$ & & $(0.18)$ & \\
Willingness to migrate again & & & -0.023 & -0.023 & \\
& & & $(0.61)$ & $(0.62)$ & \\
Openness index & & & & & -0.034 \\
& & & & & $(0.53)$ \\
\hline R2 & 0.29 & 0.31 & 0.31 & 0.31 & 0.31 \\
N & 243 & 234 & 233 & 233 & 233 \\
\hline
\end{tabular}

Notes. (I) ${ }^{* * *},{ }^{* *}$, and ${ }^{*}$ respresent $1 \%, 5 \%$ and $10 \%$ significance levels, respectively. (II) All specifications are weighted by the sampling weights provided in the dataset, with robust standard errors. (III) Dep. var. is a dummy being 1 if the returnee lived in the West, whilst it is 0 if he lived in a non-West country. (IV) Data source: IIIMD, 2013. 